\title{
HEAVY METAL TOLERANCE AND ACCUMULATION POTENTIAL OF COASTAL ACCESSIONS OF TRIFOLIUM FRAGIFERUM, A PROMISING FORAGE SPECIES
}

\author{
Gederts IEVINSH, Faculty of Biology, University of Latvia, 1 Jelgavas Str., Riga, Latvia; gederts.ievins@lu.lv (corresponding author) \\ Andis KARLSONS, Institute of Biology, University of Latvia, 4 O. Vaciesa Str., Riga, Latvia; andis.karlsons@lu.lv \\ Astra JĒKABSONE, Faculty of Biology, University of Latvia, 1 Jelgavas Str., Riga, Latvia; astra.jekabsone@lu.1v \\ Una ANDERSONE-OZOLA, Faculty of Biology, University of Latvia, 1 Jelgavas Str., Riga, Latvia; una.andersone-ozola@lu.lv
}

\begin{abstract}
The aim of the present study was to examine heavy metal tolerance of different wild accessions of strawberry clover, T. fragiferum, a promising forage species, in comparison to a commercial cultivar, and to find out if there is a tendency to accumulate heavy metals in above ground parts of strawberry clover plants. Seeds from four geographically isolated wild populations of $T$. fragiferum in Latvia as well as cv. 'Palestine' were used to establish experiment in controlled conditions using substrate gradient of $\mathrm{Cd}$ and $\mathrm{Pb}$. Similar to closely related species $T$. repens, $T$. fragiferum showed high tolerance to heavy metals $\mathrm{Cd}$ and $\mathrm{Pb}$ and excluded heavy metals from above ground parts. Some physiological differences were evident in respect to morphological responses of different accessions to the two heavy metals as well as regarding heavy metal accumulation potential in different plant parts. It was concluded that when cultivated in unpolluted soils, shoots of $T$. fragiferum can be considered safe as forage for animal consumption.
\end{abstract}

Keywords: crop wild relatives, heavy metals, strawberry clower

\section{INTRODUCTION}

Due to the need to ensure crop productivity in conditions of growing anthropogenic impact and global climate change, crop wild relatives (CWR) represent a valuable genetic source of tolerance-related characteristics (Zhang et al. 2016). CWRs can be used for development of new crop cultivars with better adaptation to growing environmental heterogeneity (Dempewolf et al. 2014).

In the Baltic Region, perennial forage legumes and grasses represent the main type of CWRs, with legumes being especially important for development of sustainable agricultural systems. Among them, different wild Trifolium species has been studied recently in the Baltic countries as pontential forage crops (Dabkevičienè, Dabkevičius 2005; Bērziṇa et al. 2008; Paplauskienè, Dabkevičienè 2012). However, extremely rare wild clover species, Trifolium fragiferum L., has not been studied and practically used in Europe, but has been cultivated in other regions because of relatively good tolerance to soil salinity, alkalinity and flooding (Townsend 1985). In the Baltic Region, T. fragiferum exclusively occurs in an endangered habitat 'Baltic coastal meadow' (A2.5b; Janssen, Rodwell 2016).

The question of possible heavy metal accumulation in plant aboveground parts has an immense practical importance for forage species as it is desired that any heavy metal contaminants are accumulated in roots but excluded from shoots. Among Trifolium species, only two of them have been relatively intensively studied in respect to heavy metal tolerance and accumulation, namely, Trifolium repens (e.g., Lopareva-Pohu et al. 2011; Lambrechts et al. 2014; Lanier et al. 2016; Xiao et al. 2020; Lin et al. 2021) and Trifolium alexandrinum (e.g., Ali et al. 2012; Sinegani et al. 2015; Bhatti et al. 2018). There is no information available in the literature on heavy metal tolerance of T. fragiferum, but closely related $T$. repens has been characterized as heavy metal-tolerant excluder species (Lanier et al. 2016). In contrast, T. alexandrinum accumulated similar concentration of particular metals, including $\mathrm{Cd}$ and $\mathrm{Pb}$, in both roots and shoots (Bhatti et al. 2018), and even has been suggested as species with high phytoextraction potential (Ali et al. 2012).

Recently we characterized abiotic stress tolerance of several wild accessions of $T$. fragiferum from coastal habitats of the Baltic Sea (Andersone-Ozola et al. 2021). Most importantly, it was shown that all accessions had relatively good tolerance against high soil moisture, trampling and cutting, but each accession from geographically isolated micropopulation had unique physiological profile. It seems to be highly likely that responses to other factors, including heavy metals, may significantly differ for different accessions of $T$. fragiferum. Therefore, the aim of the present study was to examine heavy metal tolerance of different wild accessions of $T$. fragiferum in comparison to a commercial cultivar, and to find out if there is a tendency to accumulate heavy metals in above ground parts of strawberry clover plants.

Copyright (C) 2021 The Authors. Published by Vytautas Magnus University. This is an open-access article distributed under the terms of the Creative Commons Attribution License (CC BY 4.0), which permits unrestricted use, distribution, and reproduction in any medium, provided the original author and source are credited. 


\section{MATERIALS AND METHODS}

Seeds from four geographically isolated wild accessions of T. fragiferum in Latvia were used for propagation of plants used in the present study: TF1 (wet saline meadow, Liepāja), TF2 (saline river bank near estuary (Jūrmala, Lielupe), TF4 (degraded land in urban industrial area, Rīga, Skanste), TF7 (dry coastal meadow, Ainaži). T. fragiferum cv. 'Palestine' seeds were purchased from Sheffield's Seeds Company (USA) and used as a reference genotype (TF8). Experimental details on establishment of plant material and cultivation conditions are described elsewhere (AndersoneOzola et al. 2021). Briefly, seeds were surface sterilized with $5 \% \mathrm{NaOCl}$, imbibed in water and scarified with scalpel. Prepared seeds were germinated in autoclaved substrate (Garden Soil, Biolan, Finland) in plastic plant tissue culture containers in a growth cabinet. Established seedlings with the two true leaves were individually transplanted first to 250 $\mathrm{mL}$ plastic containers and after two weeks to $1.3 \mathrm{~L}$ plastic containers filled with a mixture of heat-treated substrate containing Garden Soil and quartz sand (1:3, v/v). Plants were cultivated in an experimental automated greenhouse with supplemented light $\left(380 \mu \mathrm{mol} \mathrm{m} \mathrm{s}^{-2} \mathrm{~s}^{-1}\right.$ at the plant level) with $16 \mathrm{~h}$ photoperiod, day/night temperature $24 / 16^{\circ} \mathrm{C}$, relative air humidity 60 to $70 \%$. Substrate water content was kept at 50 to $60 \%$ using deionized water. Plants were fertilized every other week with Yara Tera Kristalon Red and Calcinit fertilizers (Yara, Norway).

One week after the last transplantation the plants were randomly distributed in seven treatments, five individual plants per treatment: control, Cd 10, Cd 50, Cd 100, Pb 100, Pb 200, Pb 500 (in mg of metal per $1 \mathrm{~L}$ of substrate). For respective treatments, $\mathrm{CdCl}_{2}$ and $\mathrm{Pb}\left(\mathrm{CH}_{3} \mathrm{COO}\right)_{2} 3 \mathrm{H}_{2} \mathrm{O}$ were used in necessary dilutions in deionized water. Plants were cultivated for four weeks after the treatment. At the termination, plants were individually separated in different parts (roots, stolons, flower stalks, inflorescences, leaf petioles, leaf blades) and both fresh and dry mass (after drying in an oven) were measured. Water content was calculated as $\mathrm{g} \mathrm{H}_{2} \mathrm{O}$ per $\mathrm{g}$ dry mass. As indicated previosuly (Andersone-Ozola et al. 2021), flower-related characteristics of $T$. fragiferum were extremely variable between individual plants, therefore, these parameters were further used only for calculation of total shoot biomass per plant, but were not analyzed as individual parameters.

Concentration of $\mathrm{Cd}$ and $\mathrm{Pb}$ was measured in dried material for all plant parts. For each plant sample approximately $2 \mathrm{~g}$ plant material was collected. Samples were fixed 2 to $3 \mathrm{~min}$ at $105{ }^{\circ} \mathrm{C}$, then dried at $60{ }^{\circ} \mathrm{C}$ to constant weight and ground. Plant tissue test solution was prepared by dry ashing with $\mathrm{HNO}_{3}$ vapor and re-dissolving in a $3 \% \mathrm{HCl}$ solution (Rinkis et al. 1987). The testing solution was used for the determination of analyzed heavy metals. Microwave plasma atomic emission spectrometry (4200 MP-AES, Agilent) was used for the measurement of $\mathrm{Pb}$ and $\mathrm{Cd}$ according to manufacturer's instructions. Analyzed element concentrations in plant tissue were expressed as $\mathrm{mg} \mathrm{kg}^{-1}$.

Results were analyzed and graphs were made by KaleidaGraph (v. 4.1, Synergy Software, USA). Statistical significance of differences between all treatments was evaluated by one-way anova using Microsoft Excel spreadsheet (www.biostathandbook.com/anova.xls) (McDonald 2014).

\section{RESULTS}

Total dry mass of $T$. fragiferum shoots was relatively little affected by increasing concentration of heavy metals in susbtrate (Fig. 1). Only for Cd-treated plants, it significantly increased for TF7 at $10 \mathrm{mg} \mathrm{kg}^{-1}$ and decreased for TF8 at $100 \mathrm{mg} \mathrm{kg}^{-1}$. Both root dry mass and leaf petiole dry mass were not significantly affected by any of treatments (data not shown). Dry mass of stolons was relatively more sensitive to heavy metal treatment. It significantly decreased for TF2 and TF4 at $50 \mathrm{mg} \mathrm{L}^{-1} \mathrm{Cd}$, and for all accessions at $100 \mathrm{mg} \mathrm{L}^{-1} \mathrm{Cd}$ (Fig. 2A). However, in the case of Pb, treatment resulted in significant increase in dry mass of stolons for TF1 (by 11 and 25\%) and TF8 (by 29 and 44\%) at 100 and $200 \mathrm{mg} \mathrm{L}^{-1}$, respectively (Fig. 2B).
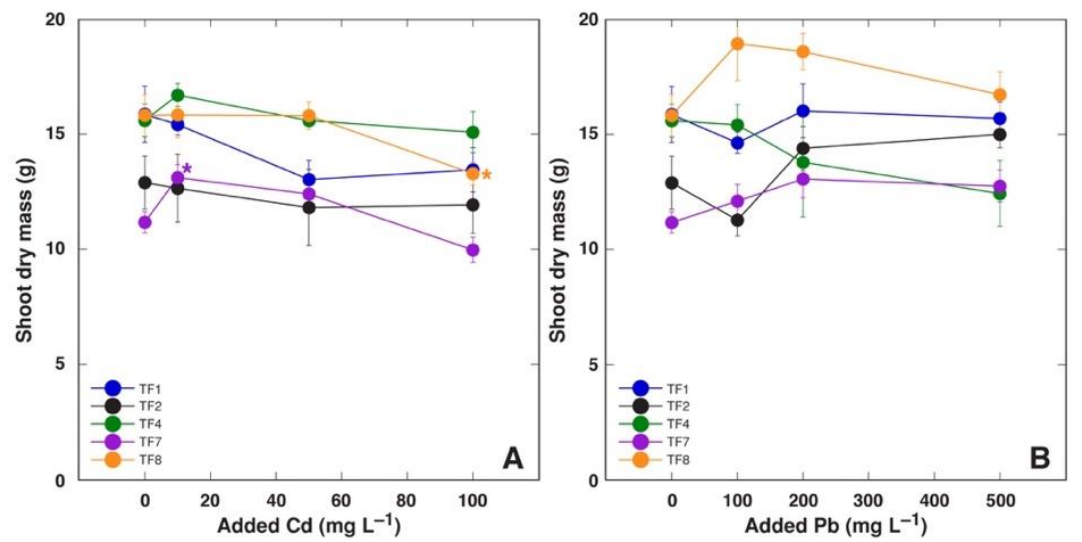

Figure 1. Effect of added substrate $\mathrm{Cd}(\mathrm{A})$ and $\mathrm{Pb}(\mathrm{B})$ on total shoot dry mass of different accessions of Trifolium fragiferum. Data are means \pm SE from 5 replicates. Asterisks of respective color indicate statistically significant differences from control $(p<0.05)$. 

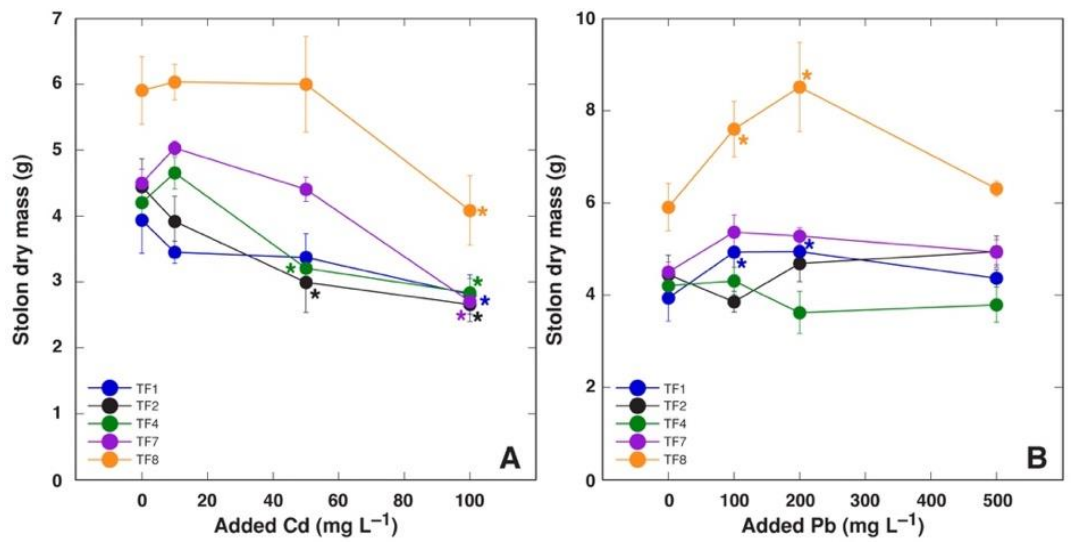

Figure 2. Effect of added substrate $\mathrm{Cd}(\mathrm{A})$ and $\mathrm{Pb}(\mathrm{B})$ on stolon dry mass of different accessions of Trifolium fragiferum. Data are means \pm SE from 5 replicates. Asterisks of respective color indicate statistically significant differences from control $(p<0.05)$.

Leaf petiole dry mass was another parameter that was affected by heavy metal treatments: it significantly decreased for TF8 at 50 and for TF1, TF7 and TF8 for $100 \mathrm{mg} \mathrm{kg}^{-1} \mathrm{Cd}$ (Fig. 3A). Besides, leaf petiole dry mass significantly decreased for TF7 for 100, 200, and $500 \mathrm{mg} \mathrm{L}^{-1} \mathrm{~Pb}$ (Fig. 3B). Water content in stolons, leaf petioles and leaf blades was not significantly affected by treatment with heavy metals (data not shown). However, root water content significanly decreased for TF1 by both $\mathrm{Cd}$ and $\mathrm{Pb}$ at all concentrations as well as for TF4 at $100 \mathrm{mg} \mathrm{L}^{-1} \mathrm{Cd}$ (Fig. 4). To summarize, Cd tolerance decreased in an order TF7, TF1 > TF4 > TF2 > TF8, but Pb tolerance decreased in an order TF8 > TF1 > TF2, TF4 > TF7.
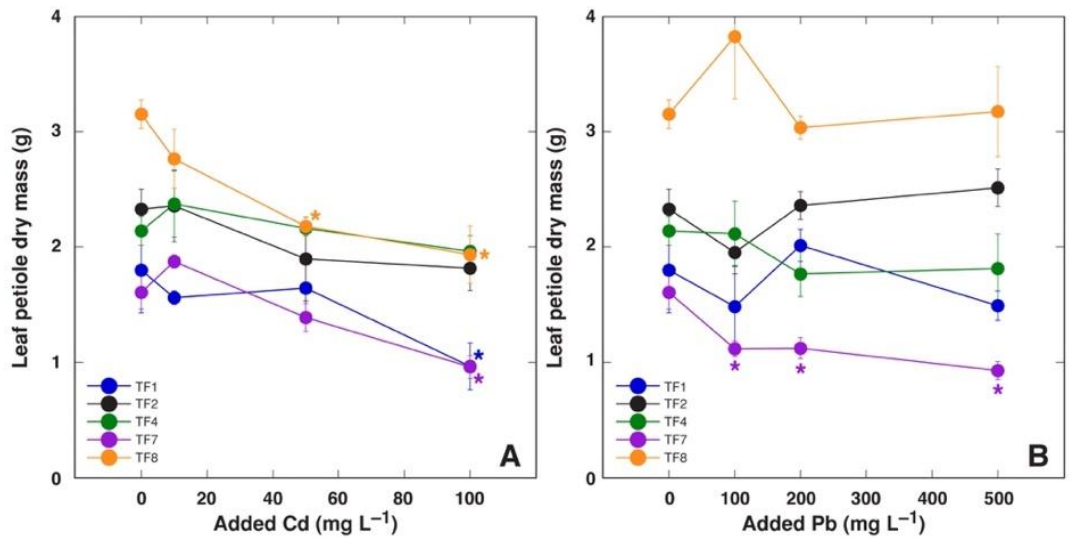

Figure 3. Effect of added substrate $\mathrm{Cd}(\mathrm{A})$ and $\mathrm{Pb}(\mathrm{B})$ on leaf petiole dry mass of different accessions of Trifolium fragiferum. Data are means \pm SE from 5 replicates. Asterisks of respective color indicate statistically significant differences from control $(p<0.05)$.
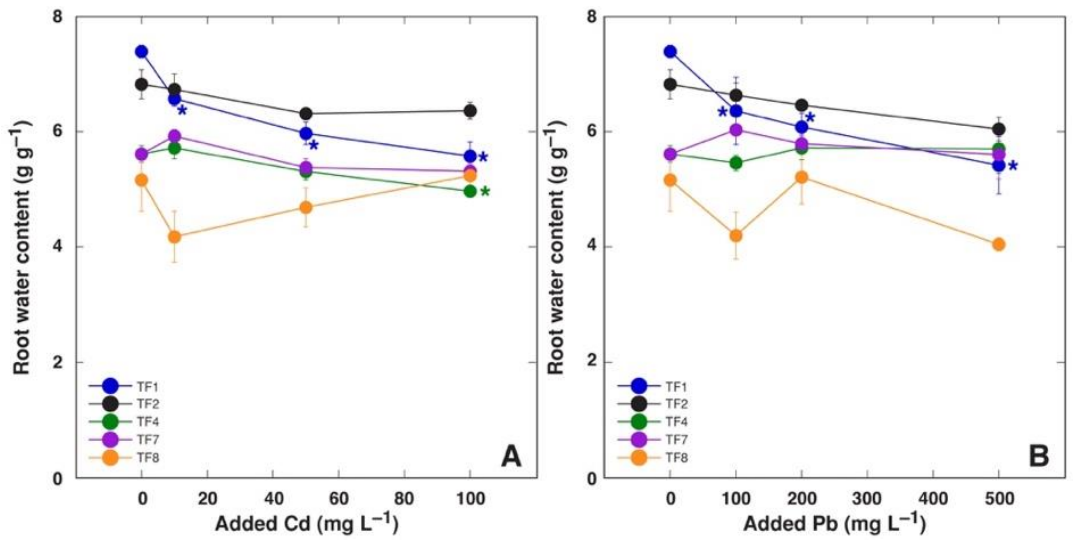

Figure 4. Effect of added substrate $\mathrm{Cd}(\mathrm{A})$ and $\mathrm{Pb}(\mathrm{B})$ on root water content of different accessions of Trifolium fragiferum. Data are means \pm SE from 5 replicates. Asterisks of respective color indicate statistically significant differences from control $(p<0.05)$.

The accumulation potential of metals was markedly different in different parts of $T$. fragiferum plants. The lowest Cd concentration was in flower stalks $\left(1.8-5.8 \mathrm{mg} \mathrm{kg}^{-1}\right)$ and flowers $(3.3-7.5 \mathrm{mg} \mathrm{kg}-1)$. The same relationship was seen for $\mathrm{Pb}$, with its concentration in flower stalks reaching $2.3-9.4 \mathrm{mg} \mathrm{kg}^{-1}$ and that in flowers $2.5-8.1 \mathrm{mg} \mathrm{kg}^{-1}$. Both $\mathrm{Cd}$ and $\mathrm{Pb}$ mainly accumulated in roots, with shoot concentrations being about 10 times lower for $\mathrm{Cd}$ (Fig. 5) and 5 to 20 times lower for $\mathrm{Pb}$ (Fig. 6) than these in roots. 

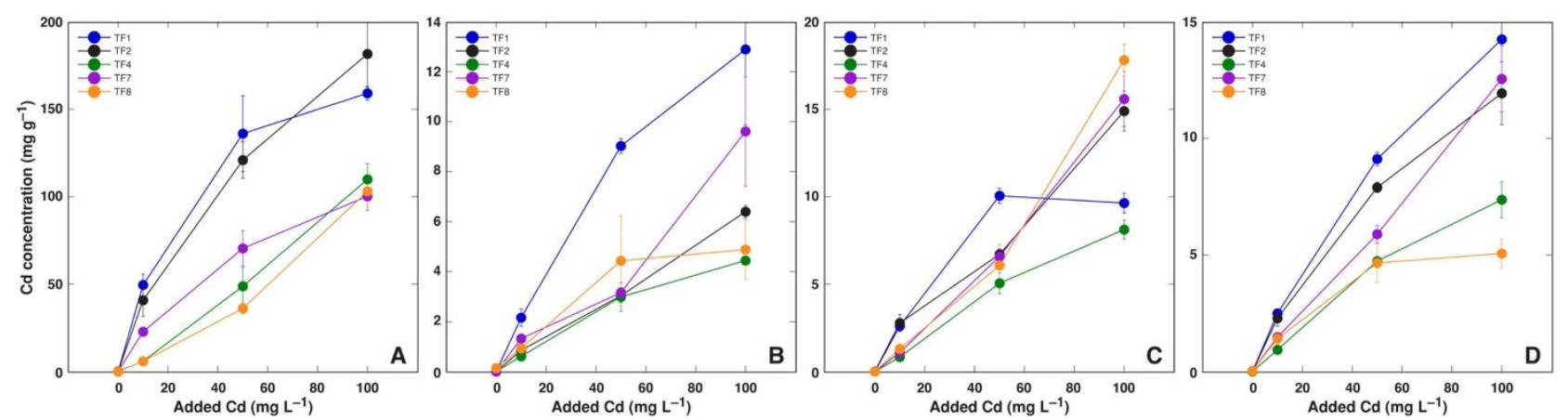

Figure 5. Cd concentration in roots (A), stolons (B), leaf petioles (C) and leaf blades (D) of different accessions of Trifolium fragiferum plants grown at different levels of substrate $\mathrm{Cd}$ concentration. Data are means $\pm \mathrm{SE}$ from 3 replicates.

Differences in metal accumulation patterns were observed between different genotypes. Thus, accessions TF1 and TF2 had higher $\mathrm{Cd}$ accumulation capacity in roots in comparison to other accessions (Fig. 5A). Similarly, TF1 accumulated more $\mathrm{Cd}$ in stolons at all treatments (Fig. 5B). TF2, TF7 and TF8 accumulated more Cd in leaf petioles at high substrate Cd concentration in comparison to TF1 and TF4 (Fig. 5C); while TF1, TF2 and TF7 accumulated more Cd at moderate and high substrate concentrations in comparison to TF4 and TF8 (Fig. 5D). Accession-specific accumulation patterns were less pronounced for $\mathrm{Pb}$, but in leaf blades saturation of accumulation was observed for TF4, TF7 and TF8 (Fig. 6D).
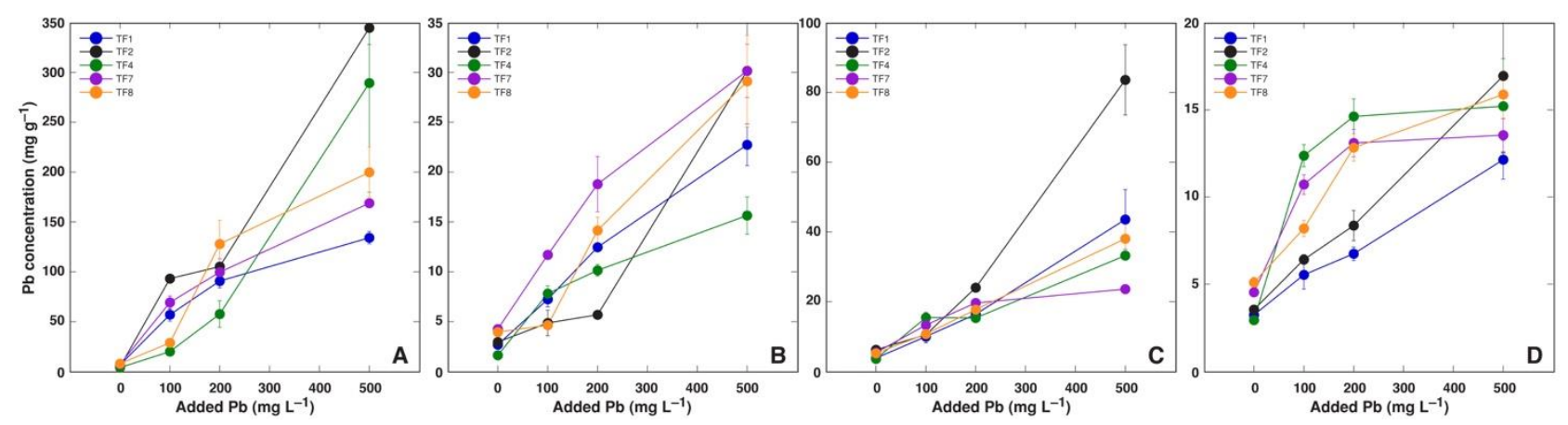

Figure 6. Pb concentration in roots (A), stolons (B), leaf petioles (C) and leaf blades (D) of different accessions of Trifolium

fragiferum plants grown at different levels of substrate $\mathrm{Pb}$ concentration. Data are means $\pm \mathrm{SE}$ from 3 replicates.

\section{DISCUSSION}

Tolerance to heavy metals and their accumulation ability in plant tissues are generally independent plant traits (Angulo-Bejarano et al. 2021). For example, even Cd hyperaccumulator species Arabidopsis halleri showed $45 \%$ decrease of shoot growth at $5 \mu \mathrm{M} \mathrm{Cd}$, reaching $82 \%$ reduction at $100 \mu \mathrm{M}$ (Zhao et al. 2006). In addition, tolerance to different heavy metals of particular species can vary significantly.

Visual symptoms of both $\mathrm{Cd}$ and $\mathrm{Pb}$ toxicity are usually associated with inhibition of plant growth and development (Pourrut et al. 2011). All accessions of $T$. fragiferum showed relatively good tolerance to increased substrate level of $\mathrm{Cd}$ and $\mathrm{Pb}$ as shown by absence of changes in root biomass and only extremely limited effect on total shoot biomass. However, several individual parts of shoot were significantly affected by heavy metal treatments although differently for different accessions. It is especially intriguing that the accession most tolerant to Cd (TF7) was the most sensitive to $\mathrm{Pb}$, but the accession most tolerant to $\mathrm{Pb}$ (TF8) was the most sensitive to $\mathrm{Cd}$. Decrease in tissue water content due to heavy metal treatment, as found in roots of TF1, relatively tolerant to both metals (Fig. 4), is considered to be the result of disruption of respiration and oxidative phosphorilation (Sharma, Dubey 2005).

Estimation of accumulation of heavy metals in above ground parts of T. fragiferum is important for its use as animal feed. Only one study can be found in the literature on heavy metal accumulation in T. fragiferum plants showing that heavy use of urban compost does not affect $\mathrm{Cd}\left(<1 \mathrm{mg} \mathrm{kg}^{-1}\right)$ and $\mathrm{Pb}\left(8 \mathrm{mg} \mathrm{kg}^{-1}\right)$ concentration in leaves (Murillo et al. 1997). However, there were no experiments performed so far on effects on growth and metal accumulation at elevated soil concentration of heavy metals for $T$. fragiferum.

The global estimated range for Cd concentration in unpolluted soils is between 0.06 and $1.1 \mathrm{mg} \mathrm{kg}^{-1}$, but average value for $\mathrm{Pb}$ is considered to be $25 \mathrm{mg} \mathrm{kg}^{-1}$, with maximum concentration less than $100 \mathrm{mg} \mathrm{kg}^{-1}$ (Kabata-Pendias, Mukherjee 2007). At minimum Cd $\left(10 \mathrm{mg} \mathrm{L}^{-1}\right)$ and $\mathrm{Pb}\left(100 \mathrm{mg} \mathrm{L}^{-1}\right)$ treatments used in the present study, maximum metal accumulation in above-ground parts was in leaf petioles, with mean values for all accessions 1.7 and $12 \mathrm{mg} \mathrm{kg}^{-1}$, for Cd and $\mathrm{Pb}$, respectively. With the average water content in leaf petioles being $4.5 \mathrm{~g} \mathrm{~g}^{-1}$ dry mass, respective metal concentrations on fresh mass basis were $0.3 \mathrm{mg} \mathrm{kg}^{-1}$ for $\mathrm{Cd}$ and $2.2 \mathrm{mg} \mathrm{kg}^{-1}$ for $\mathrm{Pb}$. Consequently, even at the maximum level of $\mathrm{Cd}$ and $\mathrm{Pb}$ in relatively unpolluted agricultural soil, accumulation potential of $\mathrm{Cd}$ and $\mathrm{Pb}$ in above ground parts of $T$. fragiferum could be significantly lower than permissable maximum concentration of these metals in forage material ( $1 \mathrm{mg} \mathrm{kg}^{-1}$ fresh mass for Cd and $30 \mathrm{mg} \mathrm{kg}^{-1}$ for Pb) (EFSA 2004a; EFSA 2004b). There is no doubt that cultivation of 
T. fragiferum in heavily metal-contaminated soils will leed to accumulation of these heavy metals in above ground parts well above permissable levels. However, both heavy metal tolerance and accumulation potential in natural conditions can be significantly affected by symbiosis with arbuscular mycorrhiza and associated rhizobacteria, as in the case of $T$. repens (Oleńska et al. 2020; Xiao et al. 2020; Xiao et al. 2021) and T. pratense (Vivas et al. 2003).

A pronounced physiological gradient of heavy metal concentration was evident for $T$. fragiferum plants in respect to both metals. Cd concentration decreased in an order roots $>$ leaf petioles $>$ leaf blades $>$ stolons $>$ flowers $>$ flower stalks, but $\mathrm{Pb}$ concentration decreased in an order roots $>$ leaf petioles $>$ stolons $>$ leaf blades $>$ flowers $>$ flower stalks. This is consistent with a general opinion that, for a majority of plants, $\mathrm{Cd}$ is preferentially accumulated in roots, with significantly lower concentration in leaves and even less in reproductive organs (Grant et al. 1998). Only Cd hyperaccumulator species can reach shoot Cd concentration similar to that in roots (Zhao et al. 2006) or even higher (Roosens et al. 2003). Similarly, Pb concentration in various plants decreases in an order roots $>$ leaves $>$ stems $>$ inflorescences $>$ seeds (Sharma, Dubey 2005). In contrast, as an extreme example, Fagopyrum esculentum plants accumulated as much as $8000 \mathrm{mg} \mathrm{kg}^{-1} \mathrm{~Pb}$ in leaves, with root concentration reaching $3300 \mathrm{mg} \mathrm{kg}^{-1}$ with no negative effect on plant growth (Tamura et al. 2005). Accumulation range for Cd in $T$. fragiferum was relatively lower to that of $T$. repens, where shoot Cd concentration reached $30 \mathrm{mg} \mathrm{kg}^{-1}$, with root concentration being $500 \mathrm{mg} \mathrm{kg}^{-1}$ (Xiao et al. 2021). In respect to $\mathrm{Pb}$, values very similar than these found in the present study were reported for T. repens: $167 \mathrm{mg} \mathrm{kg}^{-1}$ in roots and $36 \mathrm{mg} \mathrm{kg}^{-1}$ in shoots (Bidar et al. 2007).

Cd toxicity usually appears at tissue concentration of $5-10 \mathrm{mg} \mathrm{kg}^{-1}$, but that for $\mathrm{Pb}$ at $10-20 \mathrm{mg} \mathrm{kg}^{-1}$ (White, Brown 2010). These concentrations were clearly exceeded in the present study. However, no direct relationship between tissue heavy metal concentration in various accessions of $T$. fragiferum and their tolerance has been observed. Similarly, even plants native to mine tailing area with potential for $\mathrm{Cd}$ phytostabilization, such as Athyrium wardii, showed significant reduction of shoot biomass at internal Cd concentration as low as $5 \mathrm{mg} \mathrm{kg}^{-1}$, further decreasing by $62 \%$ at 50

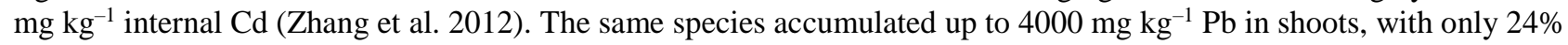
decrease in shoot biomass, possibly due to efficient compartmentalization of the metal in vacuoles of leaf cells (Zhao et al. 2015). For $T$. fragiferum, the most Cd tolerant accession TF7 accumulated $12-15 \mathrm{mg} \mathrm{kg}^{-1} \mathrm{Cd}$ in leaves and $10 \mathrm{mg}$ $\mathrm{kg}^{-1} \mathrm{Cd}$ in stolons (Fig. 6) with $40 \%$ reduction in leaf petiole and stolon biomass (Fig. 2A). Accession TF8, being most tolerant to $\mathrm{Pb}$, showed no negative effect on shoot growth while accumulating $29 \mathrm{mg} \mathrm{kg}^{-1} \mathrm{~Pb}_{\text {in }}$ stolons and even $38 \mathrm{mg}$ $\mathrm{kg}^{-1} \mathrm{~Pb}$ in leaf petioles (Fig. 7). Moreover, 44\% stimulation of stolon growth for this accession was achieved (Fig. 2B) at internal $\mathrm{Pb}$ concentration in stolon tissues reaching $14 \mathrm{mg} \mathrm{kg}^{-1} \mathrm{~Pb}$ (Fig. 7). Thus, accessions of T. fragiferum can be characterized as heavy metal tolerant species excluding metals from above ground parts.

\section{CONCLUSIONS}

Several wild accessions of $T$. fragiferum from coastal habitats of the Baltic Sea show high tolerance to heavy metals $\mathrm{Cd}$ and $\mathrm{Pb}$. However, some physiological differences are seen in respect to morphological responses of different accessions to the two heavy metals.

Similar to closely related species $T$. repens, $T$. fragiferum excludes heavy metals from above ground parts. Even at high substrate heavy metal level, their concentration in above ground parts is many times lower than that in roots. When cultivated in unpolluted soils, shoots of $T$. fragiferum can be considered safe as forage for animal consumption.

Acknowledgments. The study was supported by the Latvian Science Council project lzp-2020/2-0349 "Molecular, physiological and ecological evaluation of Latvian genetic resources of valuable wild legume species, Trifolium fragiferum, in a context of sustainable agriculture".

\section{REFERENCES}

1. Ali H., Naseer M., Sajad M.A. 2012. Phytoremediation of heavy metals by Trifolium alexandrinum. International Journal of Environmental Sciences, Vol. 2, pp. 1459-1469. https://doi.org/10.6088/ijes.00202030031

2. Andersone-Ozola U., Jēkabsone A., Purmale L., Romanovs M., Ievinsh G. 2021. Abiotic stress tolerance of coastal accessions of a promising forage legume species, Trifolium fragiferum. Plants, Vol. 10, 1552. https://doi.org/10.3390/plants10081552

3. Angulo-Bejarano P.I., Puente-Rivera J., Cruz-Ortega R., 2021. Metal and metalloid toxicity in plants: an overview on molecular aspects. Plants, 10: 635. https://doi.org/10.3390/plants10040635

4. Bērziņa I., Zhuk A., Veinberga I., Rashal I., Runǵis D. 2008. Genetic fingerprinting of Latvian red clover (Trifolium pratense L.) varieties using simple sequence repeat (SSR) markers: Comparison over time and space. Latvian Journal of Agronomy, Vol. 11, pp. $28-33$.

5. Bhatti S.S., Kumar V., Sambyal V., Singh J., Nagpal A.K. 2018. Comparative analysis of tissue compartmentalized heavy metal uptake by common forage crop: A field experiment. Catena, Vol. 16, pp. 185-193. https://doi.org/10.1016/j.catena.2017.09.015

6. Bidar G., Garçon G., Pruvot C., Dewaele D., Cazier F., Douay F., Shirali P. 2007. Behavior of Trifolium repens and Lolium perenne growing in a heavy metal contaminated field: Plant metal concentration and phytotoxicity. Environmental Pollution, Vol. 147, pp. 546-553. https://doi.org/10.1016/j.envpol.2006.10.013

7. Dabkevičiene G., Dabkevičius Z. 2005. Evaluation of wild red clover (Trifolium pratense L.) ecotypes and hybrid populations (Trifolium pratense L. x Trifolium diffusum Ehrh.) for clover rot resistance (Sclerotinia trifoliorum Erikss.). Biologija, Vol. 3, pp. 54-58.

8. Dempewolf H., Eastwood R.J., Guarino L., Khoury C.K., Müller J.V., Toll J. 2014. Adapting agriculture to climate change: A global initiative to collect, conserve, and use crop wild relatives. Agroecology and Sustainable Food Systems, Vol. 8, pp. 369-377. https://doi.org/10.1080/21683565.2013.870629

9. EFSA, 2004a. Opinion on the Scientific Panel on Contaminants in the Food Chain on a request from the Comission related to cadmium as undesirable substance in animal feed. Adopted on 2 June 2004. EFSA Journal, Vol. 72, pp. 1-24. $\underline{\text { https://doi.org/10.2903/j.efsa.2004.72 }}$ 
10. EFSA, 2004b. Opinion on the Scientific Panel on Contaminants in the Food Chain on a request from the Comission related to lead as undesirable substance in animal feed. Adopted on 2 June 2004. EFSA Journal, Vol. 71, pp. 1-20. https://doi.org/10.2903/j.efsa.2004.71

11. Grant C.A., Buckley W.T., Bailey L.D., Selles F. 1998. Cadmium accumulation in crops. Canadian Journal of Plant Science, Vol. 78, pp. 1-17. https://doi.org/10.4141/P96-100

12. Janssen J.A.M., Rodwell J.S., 2016. European Red List of Habitats: Part 2. Terrestrial and Freshwater Habitats; European Union: Brussels, Belgium.

13. Kabata-Pendias A., Mukherjee A.B. 2007. Trace Elements from Soil to Human. Springer-Verlag, Berlin, Heidelberg. https://doi.org/10.1007/978-3-540-32714-1

14. Lambrechts T., Lequeue G., Lobet G., Godin B., Bielders C.L., Lutts S.,2014. Comparative analysis of Cd and Zn impacts on root distribution and morphology of Lolium perenne and Trifolium repens: implications for phytostabilization. Plant and Soil, Vol. 376, pp. 229-244. https://doi.org/10.1007/s11104-013-1975-7

15. Lanier C., Bernard F., Dumez S., Leclercq J., Lemière S., Vandenbulcke F., Nesslany F., Platel A., Devred L., Cuny D., Deram A. 2016. Combined effect of $\mathrm{Cd}$ and $\mathrm{Pb}$ spiked field soils on bioaccumulation, DNA damage, and peroxidase activities in Trifolium repens. Environmental Science and Pollution Research, 23, pp. 1755-1767https://doi.org/10.1007/s11104-013-1975-7

16. Lin H., Liu C., Li B., Dong Y. 2021. Trifolium repens L. regulated phytoremediation of heavy metal contaminated soil by promoting soil enzyme activities and beneficial rhizosphere associated microorganisms. Journal of Hazardous Materials, Vol. 402, 123829. https://doi.org/10.1016/j.jhazmat.2020.123829

17. Lopareva-Pohu A., Verdin A., Garçon G., Sahraoui A.L.-H., Pourrut B., Debiane D., Waterlot C., Laruelle F., Bidar G., Douay F., Shirali P. 2011. Influence of fly ash aided phytostabilisation of $\mathrm{Pb}, \mathrm{Cd}$ and $\mathrm{Zn}$ highly contaminated soils on Lolium perenne and Trifolium repens metal transfer and physiological stress. Environmental Pollution, Vol. 159, pp. $1721-1729$. https://doi.org/10.1016/j.envpol.2011.02.030

18. McDonald J.H. 2014. Handbook of Biological Statistics. 3rd Ed. Sparky House Publishing: Maryland, USA, 299 p.

19. Murillo J.M., Cabrera F., López R., 1997. Response of clover Trifolium fragiferum L. cv. 'Salina' to a heavy urban compost application. Compost Science and Utilization, Vol. 5, pp. 15-25. https://doi.org/10.1080/1065657X.1997.10701893

20. Oleńska E., Imperato V., Małek W., Włostowski T., Wójcik M., Swiecicka I., Vangrosveld J., Thijs S. 2020. Trifolium repensassociated bacteria as a potential tool to facilitate phytostabilization of zinc and lead polluted waste heaps. Plants, Vol. 9, 11002. https://doi.org/10.3390/plants9081002

21. Paplauskienė V., Dabkevičienė G. 2012. A study of genetic diversity in Trifolium hybridum varieties using morphological characters and ISSR markers. Žemdirbysté=Agriculture, Vol. 99, pp. 313-318.

22. Pourrut B., Shahid M., Dumat C., Winterton P., Pinelli E. 2011. Lead uptake, toxicity, and detoxification in plants. Reviews of Environmental Contamination and Toxicology, Vol. 213, pp. 113-136. https://doi.org/10.1007/978-1-4419-9860-6_4

23. Rinkis G.J., Ramane H.K., Kunickaya T.A. 1987. Methods of Soil and Plant Analysis. Zinatne, Riga, 174 pp. [in Russian]

24. Roosens N., Verbruggen N., Meerts P., Ximénez-Embún P., Smith J.A.C. 2003. Natural variation in cadmium tolerance and its relationship to metal hyperaccumulation for seven populations of Thlaspi caerulescens from western Europe. Plant Cell Environment, Vol. 26, pp. 1657-1672. https://doi.org/10.1046/j.1365-3040.2003.01084.x

25. Sharma P., Dubey R.S. 2005. Lead toxicity in plants. Brazilian Journal of Plant Physiology, Vol. 17, pp. $35-52$. https://doi.org/10.1590/S1677-04202005000100004

26. Sinegani S.S., Abedi A., Asghari H.R., Sinegani A.A.S. 2015. Using Trifolium alexandrinum for phytoremediation of some heavy metals in tailings dam in Anjir-Tange coal washing plant, Mazandran, Iran. Journal of Mining and Environment, Vol. 6, pp. 141-150.

27. Tamura H., Honda M., Sato T., Kamachi H. 2005. Pb hyperaccumulation and tolerance in common buckwheat (Fagopyrum escculentum Moench). Journal of Plant Research, Vol. 118, pp. 355-359. https://doi.org/10.1007/s10265-005-0229-z

28. Townsend C.E., 1985. Miscellaneous perennial clovers. In: Taylor J.L. (Ed.) Clover Science and Technology. ASA/CSSA/SSSA, Madison, Wisconsin, pp. 563-578. https://doi.org/10.2134/agronmonogr25.c26

29. Vivas A., Azcón R., Biró B., Barea J.M., Ruiz-Lozano J.M. 2003. Influence of bacterial strains isolated from lead-polluted soil and their interactions with arbuscular mycorrhizae on the growth of Trifolium pratense L. under lead toxicity. Canadian Journal of Microbiology, Vol. 49, pp. 577-588. https://doi.org/10.1139/w03-073

30. White P.J., Brown P.H. 2010. Plant nutrition for sustainable development and global health. Annals of Botany, Vol. 105, pp. 1073-1080. https://doi.org/10.1093/aob/mcq085

31. Xiao Y., Liu M., Chen L., Ji L., Zhao Z., Wang L., Wei L., Zhang Y. 2020. Growth and elemental uptake of Trifolium repens in response to biochar addition, arbuscular mycorrhizal fungi and phosphorus fertilizer applications in low-Cd-polluted soils. Enviromental Pollution, Vol. 260, 113761. https://doi.org/10.1016/j.envpol.2019.113761

32. Xiao Y., Zhao Z., Chen L., Li Y. 2021. Arbuscular mycorrhizal fungi mitigate the negative effects of straw incorporation on Trifolium repens in highly Cd-polluted soils. Appied Soil Ecology, Vol. $157,103736$. https://doi.org/10.1016/j.apsoil.2020.103736

33. Zhang H., Mittal N., Leamy L.J., Barazani O., Song B.-H. 2016. Back into the wild - Apply untapped genetic diversity of wild relatives for crop improvement. Evolutionary Applications, Vol. 10, pp. 5-24. https://doi.org/10.1111/eva.12434

34. Zhang S., Li T., Huang H., Zou T., Zhang X., Yu H., Zheng Z., Wang Y. 2012. Cd accumulation and phytostabilization potential of dominant plants surrounding mining tailings. Environmental Science and Pollution Research, Vol. 19, pp. 3879-3888. https://doi.org/10.1007/s11356-012-1060-4

35. Zhao F.J., Jiang R.F., Dunham S.J., McGrath S.P. 2006. Cadmium uptake, translocation and tolerance in the hyperaccumulator Arabidopsis halleri. New Phytologist, Vol. 172, pp. 646-654. https://doi.org/10.1111/j.1469-8137.2006.01867.x

36. Zhao L., Li T., Yu H., Chen G., Zhang X., Zheng Z., Li J. 2015. Changes in chemical forms, subcellular distribution, and thiol compounds involved in $\mathrm{Pb}$ accumulation and detoxification in Athyrium wardii (Hook.). Environmental Science and Pollution Research, Vol. 22, pp. 12676-12688. https://doi.org/10.1007/s11356-015-4464-0 